P-ISSN 2442-6636

E-ISSN 2355-3987

www.ijhn.ub.ac.id

Artikel Hasil Penelitian

\title{
Korelasi Indeks Massa Tubuh dan Kadar Albumin dengan Konversi Sputum Pasien Tuberkulosis
}

\author{
Juli Yosa Mega', Dina Keumala Sari ${ }^{2 *}$, Juliandi Harahap ${ }^{3}$ \\ ${ }^{1}$ Program Studi Magister Kedokteran Tropis/Fakultas Kedokteran/Universitas Sumatera Utara \\ ${ }^{2}$ Departemen Ilmu Gizi/ Fakultas Kedokteran/Universitas Sumatera Utara \\ ${ }^{3}$ Departemen Ilmu Kedokteran Komunitas/ Fakultas Kedokteran/Universitas Sumatera Utara \\ *Alamat korespondensi: Email: dina@usu.ac.id, Tlp:+6281397177693
}

\begin{abstract}
Abstrak
Tuberkulosis (TB) masih menjadi masalah utama kesehatan di Indonesia termasuk di Propinsi Sumatera Utara. Telah dilaporkan efikasi yang baik dari pengobatan TB di berbagai daerah, keberhasilan pengobatan TB dipengaruhi oleh banyak factor termasuk status nutrisi. Penelitian ini bertujuan untuk menemukan adanya hubungan indeks massa tubuh dan albumin dengan konversi sputum pasien tuberculosis, khususnya pasien tuberculosis paru positif kuman Basil Tahan Asam. Penelitian ini dilaksanakan di dua Pusat Kesehatan Masyarakat di Kota Medan antara bulan Oktober dan Nopember 2018. Seluruh subjek penelitian sejumlah 39 pasien TB dengan positif kuman Basil Tahan Asam ikut serta. Subjek penelitian menerima pengobatan TB sesuai panduan. Indeks masa tubuh, albumin, dan sputum diukur dengan menggunakan stature meter dan timbangan digital. Proporsi subjek penelitian di bawah normal, normal dan di atas normal adalah 13 (33.3\%), $21(53.9 \%)$ and $5(12.8 \%)$, berturut-turut. Kadar albumin termasuk kadar normal ditemukan pada 25 subjek penelitian (64.1\%), dan selebihnya termasuk kategori rendah. Indeks massa tubuh normal berhubungan bermakna dengan peningkatan kadar albumin $(p<0.05)$. setelah dua bulan pemantuan terlihat konversi sputum berhubungan bermakna dengan nilai indeks massa tubuh yang normal dan atau kadar albumin yang normal $(p<0.05)$. Simpulan yang didapat adalah status nutrisi adalah faktor penting dalam pengobatan TB.
\end{abstract}

Kata kunci: albumin, Indonesia, indeks massa tubuh, konversi sputum, tuberculosis

\begin{abstract}
Tuberculosis $(T B)$ remains a major public issue in Indonesia including in North Sumatra province. Despite reported good efficacy of TB treatment in the region, the success of treatment depends on many factors including nutritional status. This study aims to determine the relationship between Body Mass Index and Albumin level with sputum conversion in AFB-positive pulmonary TB patients.The study was done in two primary health centres in Medan between October and November 2018. A total of 39 newly diagnosed TB patients with confirmed AFB-positve were included in the study.Participants received TB treatment according to the national guidelines. Body mass index, albumin, and sputum were measured using a stature meter and a digital scale.The proportion of participants with below normal, normal and above normal BMI status were 13 (33.3\%), 21 (53.9\%) and 5 (12.8\%), respectively. Level of albumin was determined as normal in 25 participants (64.1\%), and the remaining as low. Normal BMI status was significantly associated with increased albumin level ( $p<0.05)$. At 2 months follow-up, the sputum conversion was observed
\end{abstract}


in 24 individuals (61.5\%), and the conversion was significantly associated with normal BMI and/or normal albumin level $(p<0.05)$. We concluded that nutritional status is an important factor in the success of TB treatment.

Keywords: albumin, body mass index, sputum conversion, tuberculosis, Indonesia

\section{PENDAHULUAN}

Tuberkulosis (TB) adalah penyakit paru-paru yang disebabkan oleh basil Mycobacterium tuberculosis (Kemenkes, 2014). Sumber penularannya berasal dari pasien TB BTA positif. Pada waktu batuk atau bersin, pasien menyebarkan kuman ke udara dalam bentuk percikan dahak (droplet nuclei). Sekali batuk dapat menghasilkan sekitar 3000 percikan dahak. Penyakit TB termasuk dalam 10 besar penyakit yang menyebabkan kematian di dunia. Berdasarkan data dinas kesehatan provinsi Sumatera Utara pada tahun 2016 ditemukan jumlah kasus baru TB mencapai 23.097 kasus dengan angka kematian 5.714 orang. Kota Medan merupakan daerah terbesar penderita TB dibanding dengan wilayah lain yang ada di Sumut. Sejak tahun 2010 kasus TB di Kota Medan terus mengalami peningkatan. Tahun 2010 perkiraan kasus baru berjumlah 3.691 jiwa, TB Paru klinis 10.164 jiwa, TB Paru Basil Tahan Asam (BTA) positif sebanyak 1.425 kasus, dengan angka penemuan kasus baru Case Detection Rate (CDR) sebanyak 38,61 persen. Adapun BTA positif yang diobati sebanyak 1.425 kasus.

Konversi sputum merupakan prediktor kuat dan awal keberhasilan terapi pada TB paru. Konversi sputum pada TB paru ditentukan berdasarkan tidak ditemukannya bakteri tahan asam (BTA) pada kultur sputum yang diambil pada akhir bulan kedua pengobatan. Konversi sputum pada kasus TB paru terjadi pada akhir bulan pertama (60$80 \%$ ), pada akhir bulan kedua (95\%), dan 9\% tidak mengalami konversi (Tabrani, 2007). Faktor - faktor yang mempengaruhi keberhasilan konversi pada pengobatan fase intensif adalah kehidupan dan pekerjaan, akses pelayanan kesehatan, ketahanan pangan dan perilaku (kepatuhan minum obat, konsumsi alkohol, kebiasaan merokok dan status gizi) (Lonnroth, 2011).

Salah satu ukuran praktis dan murah yang dapat digunakan untuk menggambarkan status gizi adalah Indeks Massa Tubuh (IMT). Dari hasil penelitian Tama et al (2016) menemukan bahwa Pasien TB paru BTA positif dengan IMT $<18,5 \mathrm{~kg} / \mathrm{m}^{2}$ memiliki probabilitas kumulatif gagal konversi yang lebih besar dibandingkan pasien yang memiliki IMT >18,5 $\mathrm{kg} / \mathrm{m}^{2}$. Kecepatan terjadinya konversi sputum (hazard rate) pada pasien dengan IMT $<18,5 \mathrm{~kg} / \mathrm{m}^{2}$ lebih rendah dibandingkan dengan pasien dengan IMT > 18,5 kg/ $\mathrm{m}^{2}$. Waktu konversi sputum akan semakin lama jika peningkatan berat badan yang dialami oleh pasien di akhir tahap intensif $<1$ kg. Oleh karena itu, pasien TB yang memiliki IMT rendah di awal pengobatan perlu dimonitoring perkembangan status gizinya. Perbaikan status gizi pasien selama masa pengobatan harus menjadi fokus perhatian, mengingat peningkatan berat badan di akhir tahap intensif memiliki kontribusi yang cukup penting dalam terjadinya konversi sputum.

Albumin merupakan salah satu indikator status gizi, baik pada saat awal kejadian malnutrisi maupun ketika perbaikan mulai terjadi (Sridevi, 2015). Kadar albumin dalam serum turun secara bermakna pada penderita TB, dan penyebab penurunannya diduga adalah faktor gizi (asupan makan rendah, anoreksia, peningkatan katabolisme), enteropati dan reaksi 
protein fase akut (Prastowo et al, 2016). Penurunan nilai protein total dan kadar albumin ini dapat disebabkan oleh terjadinya penurunan nafsu makan pada pasien, malnutrisi dan malabsorbsi sering terjadi pada pasien tuberkulosis (Memon, 2014). Dari hasil penelitian Simbolon et al (2016) menemukan bahwa pasien TB Paru yang memiliki kadar albumin < 3,5 g/dL sebesar $(69,76 \%)$ dan sisanya sebesar $(30,24 \%)$ memiliki kadar albumin $\geq 3,5 \mathrm{~g} / \mathrm{dL}$. Hasil ini menunjukan bahwa lebih banyak pasien tuberkulosis yang memiliki kadar albumin $<3,5 \mathrm{~g} / \mathrm{dL}$. Hal ini disebabkan inflamasi kronik karena penyakit tuberkulosis dapat menyebabkan penurunan produksi albumin dan peningkatan penghancuran albumin sehingga terjadi keadaan yang disebut hipoalbuminemia atau kekurangan albumin dalam darah (Martina, 2012).

Berdasarkan penelitian diatas, maka dilakukan penelitian yang bertujuan melihat korelasi indeks massa tubuh dan kadar albumin dengan konversi sputum pasien tuberculosis.

\section{METODE PENELITIAN \\ Desain Penelitian}

Jenis penelitian yang dilakukan adalah kuantitatif dengan menggunakan desain correlation study dengan pendekatan cross sectional. Penelitian ini dilaksanakan di Puskesmas Amplas dan Teladan Medan dengan waktu penelitian selama 2 (dua) bulan sejak 1 Oktober 2018 samapi 30 November 2018.

\section{Sumber Data}

Pemeriksaan dahak penderita dilakukan di Laboratorium Puskesmas Amplas dan Teladan dengan menggunakan metode Ziehl Neelsen. Pengumpulan dahak dengan metode SPS (Sewaktu-Pagi-Sewaktu) 3 kali.
Dahak yang diambil tandai sesuai dengan nama penderita. OAT yang digunakan adalah Rifampisin, INH, Pirazinamid, Streptomisin, Etambutol dengan dosis yang disesuaikan dengan berat badan penderita (Kemenkes, 2014).

\section{Sasaran Penelitian}

Populasi penelitian ini adalah pasien TB paru kasus baru dengan BTA (+) di Puskesmas Teladan dan Puskesmas Amplas. Sampel adalah semua pasien TB paru BTA (+) yang memenuhi kriteria inklusi dan eksklusi. Kriteria Inklusi adalah Penderita berusia $>16$ tahun ; Didiagnosis sebagai penderita TB paru kasus baru dengan BTA (+) ; Penderita TB paru yang menjalani pengobatan rutin di Puskesmas Teladan dan Puskesmas Amplas ; Penderita TB paru bersedia ikut serta dalam penelitian dan mengisi informed consent. Kriteria Ekslusi adalah Wanita hamil; Penderita TB paru dengan penyakit penyerta DM atau HIV; TB kategori II. Jumlah sampel sebanyak 39 pasien dengan menggunakan rumus Slovin.

\section{Pengembangan Instrumen dan Teknik Pengumpulan Data}

Pemeriksaan BTA dilakukan sebelum pengobatan, minggu 2, minggu 8 setelah pengobatan fase intensif. Data konversi sputum pasien diambil dari kartu pengobatan pasien TB 01 .

Pengukuran berat badan dan tinggi badan pasien dilakukan di Puskesmas pada saat pasien datang berobat sekaligus anamnese secara umum riwayah penyakit, jenis kelamin, umur, pendidikan, pekerjaan dan sebagainya. Data IMT pasien diambil dari rekam medik pasien, karena seluruh data dicatat pada awal pemeriksaan, untuk mendapatkan data status nutrisi awal pasien. Pengukuran dilakukan dengan 
menggunakan timbangan digital dan stature meter.

Pemeriksaan kadar albumin pasien dilakukan dengan mengambil darah vena sejumlah 3 cc selanjutnya darah vena didiamkan tanpa antikoagulan selama 10 menit. Setelah 10 menit disentrifuge dengan kecepatan $3000 \mathrm{rpm}$ selama 5 menit. Serum yang terletak di bagian atas dipisahkan dengan mikropipet untuk diperiksa. Pengukuran kadar serum albumin dilakukan dengan metode bromcresol green (BCG).

\section{Teknik Analisis Data}

Data dianalisis secara univariat dan bivariat dengan bantuan SPSS versi 17. Analisis univariat bertujuan untuk mendeskripsikan karakteristik dari variabel Indeks Massa Tubuh, Kadar Albumin dan Hasil Konversi Sputum BTA. Analisis bivariat (chi-square) bertujuan untuk mengetahui hubungan antara Indeks Massa Tubuh dan Kadar Albumin dengan Konversi Sputum.

\section{Persetujuan Etik}

Penelitian ini telah disetujui oleh Komite Etik Fakultas Kedokteran Universitas Sumatera Utara dan Rumah Sakit Umum Pusat Haji Adam Malik, Medan, No. 96/TGL/KEPK FK USURSUP HAM/2018) dan seluruh subjek penelitian telah memberikan persetujuan ikut serta dalam penelitian secara tertulis.

\section{HASIL PENELITIAN \\ Karakteristik Responden}

Dari 39 responden didapatkan laki-laki sebanyak 22 orang $(56,41 \%)$ dan perempuan sebanyak 17 orang (43.59\%). Usia responden berdasarkan usia berkisar antara 18 tahun - 70 tahun dengan rerata $43,23 \pm 15,45$. Jumlah pasien TB paru paling banyak berada pada usia yang masih produktif (16-55 tahun) sebanyak 28 orang $(71,79 \%$.). Responden berdasarkan tingkat pendidikan diperoleh bahwa jumlah pasien TB paru paling banyak lulusan SMA sebanyak 27 orang $(69,23 \%)$. Responden yang memiliki pekerjaan sebanyak 28 orang $(71,79 \%)$.

Tabel 1. Karakteristik Responden

\begin{tabular}{lccc}
\hline Karakteritik & n & \% & Rerata \pm SD \\
\hline Jenis Kelamin : & 22 & 56.41 & \\
Laki-Laki & 17 & 43.59 & \\
Perempuan & & & $43.23 \pm 15.45$ \\
Usia : & 13 & 33.33 & \\
$16-35$ tahun & 15 & 38.46 & \\
$36-55$ tahun & 11 & 28.21 & \\
$56-75$ tahun & & & \\
Tingkat Pendidikan : & 4 & 10.26 & \\
SD & 7 & 17.95 & \\
SMP & 27 & 69.23 & \\
SMA & 1 & 2.56 & \\
Perguruan Tinggi & & & \\
Pekerjaan : & 34 & 87.18 & \\
Bekerja & 5 & 12.82 & \\
Tidak bekerja & &
\end{tabular}

\section{Indeks Massa Tubuh}

Indeks Massa Tubuh responden berkisar antara 15,14 - 32,19 dengan rerata $20,82 \pm 4,05$. Dari tabel tersebut, diketahui dari 39 responden terdapat 13 orang $(33,33 \%)$ pasien memiliki IMT < 
$18,5 \mathrm{~kg} / \mathrm{m}^{2}$ (kurus), 21 orang $(53,85 \%)$ pasien memiliki IMT $<18,5-25 \mathrm{~kg} / \mathrm{m}^{2}$ (normal) dan 5 orang $(12,82 \%)$ pasien memiliki IMT > $25 \mathrm{~kg} / \mathrm{m}^{2}$ (gemuk).
Hasil ini mendapatkan mayoritas responden pada saat diagnosis memiliki Indeks Massa Tubuh $>18,5-25 \mathrm{~kg} / \mathrm{m}^{2}$ (normal).

Tabel 2. Distribusi Sampel berdasarkan IMT

\begin{tabular}{lccc}
\hline Karakteritik & n & \% & Rerata \pm SD \\
\hline Indek Massa Tubuh $\left(\mathrm{kg} / \mathrm{m}^{2}\right)$ & & & $20.82 \pm 4.05$ \\
Kurus $\left(<18,5 \mathrm{~kg} / \mathrm{m}^{2}\right)$ & 13 & 33,33 & \\
Normal $\left(>18,5-25 \mathrm{~kg} / \mathrm{m}^{2}\right)$ & 21 & 53,85 & \\
Gemuk $\left(>25 \mathrm{~kg} / \mathrm{m}^{2}\right)$ & 5 & 12,82 & \\
Total & $\mathbf{3 9}$ & $\mathbf{1 0 0 , 0 0}$ & \\
\hline
\end{tabular}

\section{Kadar Albumin}

Kadar albumin responden berkisar antara $3,10 \mathrm{~g} / \mathrm{dL}-4,50 \mathrm{~g} / \mathrm{dL}$ dengan rerata $3,73 \pm 0,39$. Dari tabel tersebut, diketahui dari 39 responden sebanyak 25 orang
$(64,10 \%)$ pasien memiliki kadar albumin $\geq$ $3,5 \mathrm{~g} / \mathrm{dL}$ dan 14 orang $(35,90 \%)$ pasien memiliki kadar albumin $<3,5 \mathrm{~g} / \mathrm{dL}$. Hasil ini mendapatkan lebih banyak responden yang memiliki kadar albumin $\geq 3,5 \mathrm{~g} / \mathrm{dL}$.

Tabel 3. Distribusi Sampel berdasarkan Kadar Albumin

\begin{tabular}{cccc}
\hline Karakteritik & n & \% & Rerata \pm SD \\
\hline Kadar albumin $(\mathrm{g} / \mathrm{dL})$ & & & $3.73 \pm 0.39$ \\
$\geq 3.5 \mathrm{~g} / \mathrm{dL}$ & 25 & 64,10 & \\
$<3.5 \mathrm{~g} / \mathrm{dL}$ & 14 & 35,90 & \\
Total & $\mathbf{3 9}$ & $\mathbf{1 0 0 , 0 0}$ & \\
\hline
\end{tabular}

\section{Hasil Konversi Sputum BTA}

Dari 39 responden yang diagnosis menderita TB paru BTA (+) sebanyak 24 orang $(61,54 \%)$ mengalami konversi sputum pada akhir pengobatan fase intensif dan 15 orang $(38,46 \%)$ tidak mengalami konversi sputum. Hasil ini mendapatkan lebih banyak responden yang mengalami konversi sputum BTA pada akhir pengobatan fase intensif.

\section{Tabel 4. Hasil Konversi Sputum BTA}

\begin{tabular}{lcc}
\hline Karakteristik & $\mathbf{n}$ & $\mathbf{\%}$ \\
\hline Konversi & 24 & 61,54 \\
\hline Tidak konversi & 15 & 38,46 \\
\hline Total & 39 & 100,00 \\
\hline
\end{tabular}

Hubungan antara Indeks Massa Tubuh dengan Konversi Sputum

Dari hasil uji silang (Tabel 5), diketahui dari 24 orang pasien TB paru yang mengalami konversi sputum terdapat 4 orang $(16,67 \%)$ dengan IMT kurus, 16 orang $(66,67 \%)$ dengan IMT normal dan 4 orang $(16,67 \%)$ dengan IMT gemuk. Dari 15 orang pasien TB paru yang tidak mengalami konversi sputum terdapat 9 orang $(60 \%)$ memiliki IMT kurus, 5 orang $(33,3 \%)$ memiliki IMT normal dan 1 orang $(6,7 \%)$ memiliki IMT gemuk. Dari hasil uji chi square diketahui nilai $\mathrm{p}$ value sebesar 0,02 artinya terdapat hubungan yang signifikan antara Indeks Massa Tubuh dengan konversi sputum.

Tabel 5. Tabulasi Silang IMT dan Konversi Sputum

\begin{tabular}{|c|c|c|c|c|c|c|c|c|c|}
\hline \multirow[t]{2}{*}{ Konversi Sputum } & \multicolumn{6}{|c|}{ Indeks Massa Tubuh (n/\%) } & \multirow{2}{*}{\multicolumn{2}{|c|}{ Total }} & \multirow{2}{*}{ p value } \\
\hline & & urus & & rmal & & emuk & & & \\
\hline Konversi & 4 & 16.67 & 16 & 66.67 & 4 & 16.67 & 24 & 61.54 & 0,020 \\
\hline Non konversi & 9 & 60.00 & 5 & 33.33 & 1 & 6.67 & 15 & 38.46 & \\
\hline Total & 11 & 33.33 & 21 & 53.85 & 5 & 12.82 & 39 & 100.00 & \\
\hline
\end{tabular}




\section{Hubungan antara Kadar Albumin dengan Konversi Sputum}

Dari hasil tabulasi silang (Tabel 6), diketahui dari 24 orang pasien TB paru yang mengalami konveris sputum BTA sebanyak 20 orang $(83,33 \%)$ pasien memiliki kadar albumin $\geq 3,5 \mathrm{~g} / \mathrm{dL}$ dan 4 orang $(16,67 \%)$ pasien memiliki kadar albumin $<3,5 \mathrm{~g} / \mathrm{dL}$. Dari 15 orang pasien
TB paru yang tidak mengalami konversi sputum sebanyak 5 orang $(33,33 \%)$ pasien memiliki kadar albumin $\geq 3,5 \mathrm{~g} / \mathrm{dL}$ dan 10 orang $(66,67 \%)$ pasien memiliki kadar albumin $<3,5 \mathrm{~g} / \mathrm{dL}$. Dari hasil uji chi square diketahui nilai $\mathrm{p}$ value sebesar 0,002 artinya terdapat hubungan yang signifikan antara kadar albumin dengan konversi sputum.

Tabel 6. Tabulasi Silang Kadar Albumin dan Konversi Sputum

\begin{tabular}{lrrrrrrr}
\hline Konversi Sputum & \multicolumn{6}{c}{ Kadar Albumin, (n/\%) } & p value \\
\cline { 2 - 7 } & $\geq 3.5 \mathrm{~g} / \mathrm{dL}$ & $<3.5 \mathrm{~g} / \mathrm{dL}$ & \multicolumn{1}{c}{ Total } & \\
\hline Konversi & 20 & 83.33 & 4 & 16.67 & 24 & 61.54 & 0,002 \\
Non konversi & 5 & 33.33 & 10 & 66.67 & 15 & 38.46 & \\
Total & $\mathbf{2 5}$ & $\mathbf{6 4 . 1 0}$ & $\mathbf{1 4}$ & $\mathbf{3 5 . 9 0}$ & $\mathbf{3 9}$ & $\mathbf{1 0 0 . 0 0}$ & \\
\hline
\end{tabular}

\section{Hubungan Indeks Massa Tubuh dengan Kadar Albumin}

Dari hasil uji silang (Tabel 7), diketahui dari 13 pasien TB paru dengan IMT kurus sebanyak 2 orang $(15,38 \%)$ pasien memiliki kadar albumin $\geq 3,5 \mathrm{~g} / \mathrm{dL}$ dan 11 orang $(84,62 \%)$ memiliki kadar albumin $<3,5 \mathrm{~g} / \mathrm{dL}$. Dari 21 orang pasien TB paru dengan IMT normal terdapat 18 orang $(85,71 \%)$ pasien memiliki kadar albumin $\geq 3,5 \mathrm{~g} / \mathrm{dL}$ dan 3 orang $(14,29 \%)$ memiliki kadar albumin $<3,5 \mathrm{~g} / \mathrm{dL}$. Dari 5 pasien TB paru gemuk terdapat 5 orang (100\%) memiliki kadar albumin $\geq 3,5$ g/dL. Dari hasil uji pearson corelation diketahui bahwa nilai $\mathrm{P}$ value sebesar 0,001 artinya terdapat hubungan yang signifikan antara Indeks Massa Tubuh dengan kadar albumin. Hal ini menyimpulkan jika Indeks Massa Tubuh pasien mengalami peningkatan maka kadar albumin juga akan meningkat.

Tabel 7. Tabulasi Silang IMT dengan Kadar Albumin

\begin{tabular}{lrrrrrrr}
\hline \multirow{2}{*}{ IMT } & \multicolumn{6}{c}{ Kadar Albumin, (n/\%) } & p value \\
\cline { 2 - 8 } & \multicolumn{2}{c}{$\geq 3.5 \mathrm{~g} / \mathrm{dL}$} & \multicolumn{2}{c}{$<.5 \mathrm{~g} / \mathrm{dL}$} & \multicolumn{1}{c}{ Total } & \\
\hline Kurus & 2 & $(15,38)$ & 11 & $(84,62)$ & 13 & $(33,33)$ & 0,001 \\
Normal & 18 & $(65,71)$ & 3 & $(14,29)$ & 21 & $(53,85)$ & \\
Gemuk & 5 & $(100,00)$ & 0 & $(0)$ & 5 & $(12,82)$ & \\
Total & $\mathbf{2 5}$ & $\mathbf{( 6 4 , 1 0 )}$ & $\mathbf{1 4}$ & $\mathbf{( 3 5 , 9 0 )}$ & $\mathbf{3 9}$ & $\mathbf{( 1 0 0 , 0 0 )}$ & \\
\hline
\end{tabular}

\section{PEMBAHASAN}

\section{Karakteristik Responden}

Jumlah pasien TB paru di Puskesmas Medan didapatkan yang berjenis kelamin laki-laki sebanyak 22 orang $(56,41 \%)$ sementara yang berjenis kelamin perempuan sebanyak 17 orang $(43.59 \%)$. Hasil ini mendapatkan pasien TB paru lebih banyak yang berjenis kelamin laki-laki. Hasil penelitian ini sejalan dengan penelitian Puspita et al (2016) yang menemukan dari 71 pasien TB paru di Poli Paru RSUD Arifin Achmad Pekanbaru didapatkan terbanyak laki-laki yaitu berjumlah 48 orang atau $67,60 \%$. Kemudian data Kementerian Kesehatan (2013) mendapatkan bahwa kejadian TB paru cenderung lebih banyak pada jenis kelamin laki-laki karena berhubungan dengan interaksi sosial yang berbeda antara 
laki-laki dan perempuan, dalam hal ini prevalensi laki-laki merokok lebih tinggi dibandingkan perempuan, begitu pula dengan kebiasaan minum minuman beralkohol, sehingga menyebabkan penurunan sistem pertahanan tubuh, sehingga apabila terpapar dengan kuman TB dapat dengan cepat menimbulkan gejala dan apabila diperiksa menjadi positif mengidap TB paru.

Pasien TB paru di Puskesmas Medan paling banyak berada pada usia yang masih produktif (16 - 55 tahun) sebanyak $71,79 \%$. Hasil penelitian ini sesuai dengan penelitian Puspita et al (2016) yang menyatakan bahwa kelompok usia pasien tuberkulosis paru berada pada kelompok usia produktif. Selanjutnya pernyataan Depkes RI tahun 2007 dalam pedoman nasional penanggulangan tuberkulosis yang menyatakan bahwa sebanyak $75 \%$ dari individu yang terinfeksi kuman TB berada dalam kelompok usia produktif (15-50 tahun). Salah satu faktor yang menyebabkan pasien TB paru berada pada kelompok usia produktif karena mereka lebih banyak menghabiskan waktunya di luar rumah untuk bekerja dan berinteraksi dengan orang lain, sehingga risiko terkena penularan penyakit $\mathrm{TB}$ menjadi lebih besar karena terjadinya kontak dengan orang yang menderita tuberkulosis paru menjadi lebih sering. Jumlah pasien TB paru di Puskesmas Medan sebagian besar merupakan lulusan SMA yaitu sebanyak 27 orang $(69,23 \%)$. Hasil penelitian ini sama dengan penelitian yang dilakukan Puspita et al (2016) yang mendapatkan bahwa distribusi pasien tuberkulosis paru yang berobat di Poli Paru RSUD Arifin Achmad Pekanbaru berdasarkan pendidikan didapatkan paling banyak berpendidikan menengah yaitu 35 orang $(49,3 \%)$. Selanjutnya hasil penelitian yang dilakukan oleh Andhika di Kabupaten Bandung Barat tahun 2012, didapatkan dari total 42 orang pasien tuberkulosis paru sebanyak 25 orang $(59,5 \%)$ berpendidikan menengah. Hasil penelitian ini bertentangan dengan teori yang dikemukakan Notoatmojo (2007) yang mengemukkan bahwa pendidikan mempengaruhi seseorang dalam penerimaan informasi kesehatan. Melalui pendidikan seorang individu dapat memahami tentang penyakit yang dideritanya. Jenjang pendidikan memegang peranan penting dalam kesehatan masyarakat. Semakin tinggi tingkat pendidikan maka semakin tinggi kemampuan untuk menerima informasi kesehatan. Hasil ini menunjukkan bahwa dari hasil penelitian-penelitian terdahulu, tingkat pendidikan seseorang menentukan status kesehatan diri orang tersebut. Lulusan SMA, tentunya lebih mempunyai informasi yang lebih banyak tentang gizi dan penyakit yang akan merubah gaya hidup seseorang lebih baik.

Jumlah pasien TB paru yang bekerja sebanyak 35 orang $(87,18 \%)$ dan yang tidak bekerja sebanyak 5 orang $(12,82 \%)$. Hasil ini menemukan mayoritas pasien TB paru di Puskesmas Medan sudah bekerja. Hal ini dapat terjadi karena lingkungan kerja merupakan tempat yang paling mudah terjadinya transmisi penyakit TB. Beberapa jenis pekerjaan tertentu memiliki resiko penyebaran dan perkembangan penyakit TB yang tinggi misalnya buruh pabrik. Hasil penelitian Tama et al (2016) juga mendapatkan sebagian besar pasien TB paru BTA positif di RSUP Persahabatan berstatus bekerja yaitu 79 orang $(65,8 \%)$. Selanjutnya penelitian Putri et al (2016) yang dilakukan di RSUD Arifin Achmad Pekanbaru pada Januari-September 2015 mendapatkan sebanyak $75 \%$ penderita TB paru telah bekerja. Sejalan dengan hasil penelitian Haryono (2012) yang menemukan bahwa lingkungan kerja menjadi salah satu faktor 
seseorang berisiko untuk terpapar kuman mycobacterium tuberculosis, karena orang yang bekerja sering berinteraksi dengan orang lain sehingga dapat mempengaruhi tingkat penularan

. Kemungkinan lainnya, disebabkan pasien yang bekerja memiliki mobilitas yang tinggi daripada yang tidak bekerja sehingga kemungkinan terpajanan oleh kuman tuberkulosis lebih tinggi. Gaya hidup seperti merokok dan risiko pekerjaan yang berasal dari polutan udara dari luar ruangan khususnya yang berhubungan dengan paparan industri juga meningkatkan risiko terinfeksi TB Paru.

\section{Indeks Massa Tubuh}

Dari hasil uji tabulasi silang menunjukkan bahwa dari 39 orang pasien TB paru di Puskesmas Medan didapatkan paling banyak pasien TB paru memiliki IMT $>18,5-25 \mathrm{~kg} / \mathrm{m}^{2}$ yaitu sebanyak 21 orang $(53,85 \%)$.. Hasil penelitian ini sejalan dengan penelitian yang dilakukan Puspita et al (2016) yang menemukan bahwa status gizi pasien TB paru berdasarkan kategori indeks massa tubuh (IMT) di Poli Paru RSUD Arifin Achmad Pekanbaru yaitu sebanyak 33 orang (46,5\%) dengan status gizi normal, 31 orang $(43,7 \%)$ dengan status gizi underweight, 4 orang $(5,6 \%)$ dengan status gizi overweight dan sebanyak 3 orang $(4,2 \%)$ dengan status gizi obesitas. Selanjutnya hasil penelitian Suliyanti tentang gambaran status gizi dan tingkat konsumsi energi protein pada pasien tuberkulosis paru di Puskesmas Medan Johor pada tahun 2013, yaitu sebanyak $51,7 \%$ pasien dengan status gizi normal. Penelitian Wokas et al (2015) juga mendapatkan lebih banyak ditemukan pasien TB paru di RSUP Prof. Dr. R. D. Kandou Manado yang memiliki IMT > 18.5 - 25 yaitu sebanyak $48,5 \%$.
Sejalan dengan penelitian terdahulu, pada penelitian ini ditemukan sebagian besar penderita TB paru mempunyai indeks massa tubuh normal, hal ini disebabkan dengan pemakaian obat secara teratur dan konseling gizi yang baik, status gizi menjadi normal. Proses perbaikan gizi tersebut seiring dengan perbaikan kondisi klinis penderita TB paru yang semakin baik ditandai dengan semakin cepatnya masa konversi sputum dan kadar albumin.

\section{Kadar Albumin}

Hasil penelitian menunjukkan dari 39 orang pasien terdapat 25 orang $(64,10 \%)$ pasien TB paru memiliki kadar albumin $\geq$ $3,5 \mathrm{~g} / \mathrm{dL}$ dan 14 orang $(35,90 \%)$ memiliki kadar albumin $<3,5 \mathrm{~g} / \mathrm{dL}$. Hasil ini menunjukkan lebih banyak pasien TB paru di Puskesmas Medan memiliki kadar albumin $\geq 3,5 \mathrm{~g} / \mathrm{dL}$. Hasil penelitian ini sejalan dengan penelitian yang dilakukan oleh Wokas et al (2015) yang mendapatkan lebih banyak pasien tuberkulosis yang memiliki kadar albumin $\geq 3,5 \mathrm{~g} / \mathrm{dL}$. Sebaliknya hasil penelitian Simbolon et al (2016) mendapatkan lebih banyak pasien tuberkulosis yang memiliki kadar albumin $<3,5 \mathrm{~g} / \mathrm{dL}$. Terjadinya perbedaan hasil penelitian ini dengan penelitian Simbolon et al (2016) dikarenakan adanya perbedaan jumlah sampel yang digunakan atau kemungkinan pasien yang mempunyai kadar albumin $\geq 3,5 \mathrm{~g} / \mathrm{dL}$ masih berada pada stadium awal penyakit Tuberkulosis. Hasil penelitian ini menunjukan bahwa dengan status nutrisi yang baik, maka terjadi perbaikan kadar albumin dan mendukung kondisi klinis pasien yang lebih baik.

\section{Konversi Sputum}

Dari hasil penelitian diperoleh bahwa pasien TB paru BTA (+) di Puskesmas Amplas dan Teladan Medan 
lebih banyak yang mengalami konversi sputum sesudah menjalani pengobatan fase intensif selama 2 bulan daripada yang tidak mengalami konversi sputum. Dari 39 pasien TB paru BTA (+) terdapat 24 orang $(61,54 \%)$ yang mengalami perubahan BTA (+) menjadi BTA (-) sedangkan yang tidak mengalami konversi sputum sebanyak 15 orang $(38,46 \%)$. Hasil penelitian ini mendapatkan lebih banyak pasien TB paru BTA (+) yang mengalami konversi sputum setelah menjalani pengobatan fase intensif selama 2 bulan yaitu sebesar 61,54\%. Hasil penelitian ini sejalan dengan penelitian Aliyah et al (2016) mendapatkan hasil konversi sputum BTA pada fase intensif sebanyak 55 subyek $(62,5 \%)$ mengalami konversi sputum dan pada 33 subyek $(37,5 \%)$ tidak mengalami konversi. Hasil penelitian Tama et al (2016) mendapatkan probabilitas kumulatif gagal konversi (survival rate) pasien TB paru sebesar $17 \%$ dan 9,2\% pasien mengalami gagal konversi. Kemudian penelitian Intiyati et al (2012) mendapatkan bahwa kesembuhan penderita TB paru berdasarkan hasil pemeriksaan sputum (BTA) sebagian besar positif sebanyak 27 orang $(57 \%)$ dan yang negatif sebanyak 20 orang $(43 \%)$.

Angka konversi adalah salah satu indikator untuk menilai kemajuan dan keberhasilan penanggulangan TB. Indikator ini berguna untuk mengetahui secara cepat hasil pengobatan dan untuk mengetahui apakah pengawasan langsung menelan obat dilakukan dengan benar (Depkes RI, 2007). Untuk menilai keberhasilan pengobatan penyakit TB paru dapat dilihat dari hasil pemeriksaan dahak pada akhir pengobatan. Konversi BTA terjadi akibat pemberian obat selama pengobatan dan merupakan prediktor keberhasilan dari pengobatan TB (PPTI 2010). Meskipun dalam penelitian ini pasien TB paru yang mengalami konversi sputum lebih besar jika dibandingkan dengan jumlah pasien TB yang tidak mengalami konversi, akan tetapi hasil tersebut tidak sesuai dengan target konversi sputum yang dikeluarkan WHO yaitu sebesar $85 \%$. Kesembuhan setiap orang berbeda disebabkan pasien memiliki respon buruk ataupun respon baik setelah pengobatan. Respon baik ditentukan oleh perubahan (konversi) sputum setelah 30 hari diberi pengobatan secara adekuat, namun respon buruk terjadi jika perubahan sputum lebih dari 30 hari (Khairil et al, 2017). Terdapat beberapa faktor yang menyebabkan gagalnya konversi sputum pada fase intensif. Di antaranya adalah kurangnya supervisi pada fase intensif, kepatuhan minum obat yang buruk, dosis obat yang tidak sesuai rekomendasi, penyakit penyerta, dan adanya TB resisten obat ganda (Liu, 2008). Faktor-faktor terjadinya kegagalan pengobatan pasien TB paru BTA (+) pada akhir pengobatan fase intensif dalam penelitian ini sehingga tidak mencapai $85 \%$ seperti yang ditargetkan pemerintah adalah tingkat kepositifan sputum pasien di awal pengobatan, IMT rendah dan kadar albumin $<3.5 \mathrm{~g} / \mathrm{dL}$. Dari 15 pasien TB paru yang tidak mengalami konversi sputum pada akhir pengobatan fase intensif terdiri dari 8 orang dengan BTA $(2+), 3$ orang dengan BTA (3) dan 4 orang dengan BTA (1+). Hasil penelitian ini mendapatkan bahwa mayoritas pasien dengan tingkat kepositifan sputum yang tinggi tidak mengalami konversi sputum. Hasil penelitian ini sejalan dengan penelitian Tama et al (2016) yang menyatakan semakin tinggi tingkat kepositifan sputum pasien di awal pengobatan, semakin besar pula probabilitas kumulatif gagal konversinya (survival rate). Pasien dengan tingkat kepositifan sputum $3+$ memiliki probabilitas kumulatif gagal konversi 
(survival rate) yang paling besar, diikuti oleh 2+, 1+, dan scanty (1-9 batang).

Mayoritas pasien TB paru yang tidak mengalami konversi sputum dalam penelitian ini memiliki IMT $<18,5 \mathrm{~kg} / \mathrm{m}^{2}$. Kegagalan konversi yang dialami oleh pasien dengan IMT kurus dapat terjadi karena adanya malabsorpsi OAT. Rendahnya status gizi pasien mempengaruhi penurunan konsentrasi obat di plasma darah dan meningkatkan fungsi ginjal untuk melakukan pembuangan. Akibatnya, efektivitas pengobatan TB menjadi tidak optimal sehingga dapat meningkatkan risiko kegagalan pengobatan pasien TB, bahkan dapat meningkatkan risiko kekambuhan (Bento et al, 2010 dalam Tama et al, 2016). Faktor terakhir yang menyebabkan kegagalan konversi sputum pada penelitian ini adalah pasien TB paru dengan kadar albumin $<3.5 . \mathrm{g} / \mathrm{dL}$. Penurunan kadar albumin akan menyebabkan penurunan jumlah ikatan albumin dengan OAT sehingga akan berdampak pada proses penyembuhan TB (Ascenzi et al, 2010 dalam Wijaya, 2015).

\section{Hubungan Indeks Massa Tubuh dengan Kadar Albumin}

Dari hasil uji Pearson correlation diperoleh bahwa nilai $\mathrm{p}$ value $=0.001<$ $\mathrm{p}=0,05$ artinya terdapat hubungan positif dan signifikan antara Indeks Massa Tubuh dengan kadar albumin. Hal ini membuktikan bahwa setiap Indeks Massa Tubuh Pasien mengalami peningkatan maka kadar albumin juga akan meningkat. Hasil penelitian ini sejalan dengan hasil penelitian Wokas et al (2015) yang mendapatkan bahwa setiap terjadi peningkatan IMT maka kadar albumin juga akan meningkat. Hal ini menggambarkan bahwa IMT mempengaruhi kadar albumin, begitu pun sebaliknya.

Selanjutnya hasil penelitian yang dilakukan Simbolon et al (2016) menemukan bahwa ada hubungan antara indeks massa tubuh dengan kadar albumin pada pasien tuberkulosis paru, dimana setiap terjadi penurunan indeks massa tubuh terjadi penurunan kadar albumin. Peningkatan asupan makan pada penderita TB akan meningkatkan kadar albumin (Prastowo et al, 2016). Hasil penelitian ini sesuai dengan teori yang menyatakan bahwa albumin adalah salah satu protein terbesar dalam plasma darah, dimana pada saat infeksi terjadi penurunan nilai plasma darah, cedera atau stres mungkin adalah penyebab peningkatan kebutuhan metabolik untuk perbaikan jaringan yang rusak dan untuk menetralisir radikal bebas yang ada di tubuh. penurunan nilai protein total dan kadar albumin ini dapat disebabkan oleh terjadinya penurunan nafsu makan pada pasien, malnutrisi dan malabsorbsi sering terjadi pada pasien tuberkulosis (Memon, 2014).

\section{Hubungan Indeks Massa Tubuh dengan Konversi Sputum}

Menurut hasil penelitian menunjukkan dari 24 pasien TB paru yang mengalami konversi sputum sebagian besar memiliki IMT > 18,5-25 kg/m ${ }^{2}$ yaitu sebanyak 16 orang $(66,67 \%)$ sementara dari 15 pasien TB paru yang tidak mengalami konversi sputum sebagian besar memiliki IMT < $18,5 \mathrm{~kg} / \mathrm{m}^{2}$ yaitu sebanyak 9 orang $(60 \%)$. Hasil ini menunjukkan pasien TB paru yang memiliki IMT $<18,5 \mathrm{~kg} / \mathrm{m}^{2}$ lebih banyak yang tidak mengalami konversi sputum, sebaliknya pasien TB paru yang memiliki IMT > 18,5 - $25 \mathrm{~kg} / \mathrm{m}^{2}$ lebih banyak yang mengalami konversi sputum. Dari hasil penelitian ini membuktikan bahwa salah satu faktor penting yang dapat mempengaruhi terjadinya keberhasilan konversi sputum BTA pada pasien TB paru adalah status gizi awal pasien pada saat didiagnosis TB. Hasil penelitian ini sesuai dengan hasil penelitian Tama et al (2016) 
yang menyatakan pasien TB paru BTA positif dengan IMT < 18,5 membutuhkan waktu yang lebih lama untuk mengalami konversi sputum dan berisiko mengalami gagal konversi sebesar 1,32 - 8,86 kali dibandingkan dengan pasien yang memiliki IMT $>18,5$.

Hasil penelitian Dillon, 1995 dalam Intiyati et al (2012) yang mengatakan penderita TB yang kurang gizi akan mengakibatkan produksi antibodi dan limfosit terhambat, sehingga proses penyembuhan menjadi terhambat. Hasil penelitian ini konsisten dengan hasil penelitian Amaliah (2012) mendapatkan bahwa penderita TB paru dengan status gizi kurus akan memiliki risiko terjadinya kegagalan konversi 3.5 kali lebih besar dibanding penderita dengan status gizi normal. Selanjutnya hasil penelitian Khariroh (2006) menemukan bahwa penderita TB dengan status gizi Kurus akan berisiko terjadi gagal konversi 8.861 kali lebih besar dari penderita TB dengan status gizi normal dan penderita TB dengan status gizi kurus sekali akan berisiko terjadi gagal konversi 30.918 kali lebih besar daripada penderita TB dengan status gizi normal.

Dari hasil uji chi square diketahui bahwa nilai $\mathrm{p}$ value sebesar $0,020<(\mathrm{p}=$ $0,05)$ artinya terdapat hubungan antara Indeks Massa tubuh dengan konversi sputum pada pasien TB paru di Puskesmas Amplas dan Teladan Medan. Hasil penelitian ini sejalan dengan penelitian Intiyani et al (2012) yang mendapatkan ada hubungan antara status gizi (IMT) dengan kesembuhan pada penderita TB paru di Poli Paru RSD Sidoarjo. Sejalan dengan penelitian Tama et al (2016) yang menyatakan bahwa status gizi pasien yang diukur dengan IMT diketahui merupakan prediktor terhadap terjadinya konversi sputum pada pasien TB paru BTA positif. Individu yang memiliki status gizi yang baik akan mampu mengembangkan respon imunitasnya sehingga proses penyembuhan tuberkulosis dapat berjalan dengan baik, sedangkan pada individu yang status gizinya buruk, mereka lebih berisiko mengalami kegagalan dalam proses penyembuhan (Claros, J.M, et al. 2014).

\section{Hubungan Kadar Albumin dengan Konversi Sputum}

Dari hasil tabulasi silang, diketahui dari 25 orang pasien yang memiliki kadar albumin $\geq 3,5 \mathrm{~g} / \mathrm{dL}$ sebanyak 20 orang $(80 \%)$ mengalami konversi sputum dan 5 orang (20\%) yang tidak mengalami konversi sputum. Sementara dari 14 orang pasien yang memiliki kadar albumin $<3,5 \mathrm{~g} / \mathrm{dL}$ sebanyak 4 orang $(28,57 \%)$ yang mengalami konversi sputum dan 10 orang (71,43\%) yang tidak mengalami konversi sputum. Dari hasil tersebut menunjukkan bahwa mayoritas pasien TB paru yang memiliki kadar albumin $\geq 3,5 \mathrm{~g} / \mathrm{dL}$ akan mengalami konversi sputum sementara pasien TB paru dengan kadar albumin < 3,5 g/dL mayoritas tidak akan mengalami konversi sputum. Hasil penelitian ini sejalan dengan penelitian Khairil et al (2017) yang menemukan mayoriatas pasien TB di Instlasi Pelayanan TB Terpadu RSUD dr. Zainoel Abidin Banda Aceh yang memiliki penurunan kadar albumin akan mengalami perbaikan klinis yang buruk yaitu sebesar 54,20\%. Selanjutnya hasil penelitian Kulsum et al (2017) mendapatkan salah satu faktor risiko gagal konversi sputum pada pasien TB adalah kadar albumin rendah. Kadar albumin sebagai faktor penjaga (protective) atau peningkatan albumin akan menurunkan kegagalan konversi sputum. Albumin sebagai alat ranspor obat seperti rifampisin yang merupakan obat terapi TB. Albumin merupakan protein plasma dan obat $\mathrm{TB}$ berikatan dengan protein plasma. Obat anti TB dimetabolisme di hepar dan 
diekskresikan bersama bilirirubin oleh empedu (Mercer et al, 2007).

Dari hasil uji statistik chi square diketahui nilai $\mathrm{p}$ value sebesar 0,002 artinya terdapat hubungan yang bermakna antara kadar alumin dengan konversi sputum. Hasil penelitian ini didukung hasil penelitian yang dilakukan Matos dan Lemos (2006) yang melaporkan bahwa albumin memiliki hubungan signifikan terhadap perubahan sputum pada pasien TB sehingga penting melakukan tindakan untuk memperbaiki status nutrisi pada pasien TB selama proses pengobatan. Perubahan sputum pada pasien TB dipengarui oleh C-Reaktif Protein (CRP) dan kadar Albumin (Profil Kesehatan Provinsi Aceh, 2012). Penelitian Kulsum et al (2017) menemukan bahwa kadar albumin darah berperan sebagai faktor protective yang akan menurunkan kegagalan konversi sputum BTA. Selanjutnya penelitian Khairil et al (2017) menemukan bahwa kadar albumin mempengaruhi perbaikan klinis pada pasien TB di Instlasi Pelayanan TB Terpadu RSUD dr. Zainoel Abidin Banda Aceh. Rifampisin sebagai obat TB paru berikatan kuat dengan albumin pada pasien TB paru. Selain rifampisin obat TB paru yang lain yaitu isoniasid juga berikatan kuat dengan albumin. Ikatan yang kuat ini diharapkan efek antimikrobial OAT meningkat sehingga menurunkan sitokin inflamasi dan mempercepat penyembuhan (Lassen et al, 2006). Penurunan kadar albumin akan menyebabkan penurunan jumlah ikatan albumin dengan OAT sehingga akan berdampak pada proses penyembuhan TB (Ascenzi et al, 2010 dalam Wijaya, 2015).

\section{SIMPULAN}

Berdasarkan hasil penelitian menunjukkan adanya hubungan yang bermakna antara Indeks Massa Tubuh dengan konversi sputum pada pasien TB paru BTA $(+)$ di Puskesmas Medan. Selain itu juga ditemukan hubungan yang bermakna antara kadar albumin dengan konversi sputum pada pasien TB paru BTA (+) di Puskesmas Medan.

\section{UCAPAN TERIMAKASIH}

Peneliti mengucapkan terimakasih kepada Kementerian Riset dan Teknologi Pendidikan Tinggi (KEMENRISTEKDIKTI) dan Lembaga Penelitian Universitas Sumatera Utara atas bantuan hibah penelitian Nomor 10/UN5.2.3.1/PPM/KP-DRPM/2019.

\section{DAFTAR RUJUKAN}

1. Perhimpunan Dokter Paru Indonesia (PDPI). 2006. Tuberkulosis Pedoman Penatalaksanaan di Indonesia. Jakarta.

2. Aliyah, Nurul S., Emmy H. Pranggono, Basti Andriyoko. 2016. Gambaran Konversi Sputum Bakteri Tahan Asam (BTA) dan Vitamin D Pada Penderita Tuberkulosis Paru Kasus Baru. CHEST Critical and Emergency Medicine Vol. 3, No. 1 Jan - Mar 201.

3. Amaliah R. 2012. Faktor- Faktor yang Berhubungan dengan Kegagalan Konversi Penderita TB Paru BTA Positif Pengobatan Fase Intensif di Kabupaten Bekasi Tahun 2010. Fakultas Kesehatan Masyarakat Universitas Indonesia. Jakarta.

4. Boirie, Y., Gachon, P., Cordat, N., Ritz, P., and Beaufre, B. 2001. Differential Insulin Sensitivities of Glucose, Amino Acid, and Albumin Metabolism in Elderly Men and Women. The Journal of Clinical Endocrinology \& Metabolism. 86:638-44

5. Claros, J.M., de Pee, S. \& Bloem, M.W. Adherence to HIV and TB Care and Treatment, the Role of Food Security and Nutrition. AIDS Behav 18, 459-464 
(2014). https://doi.org/10.1007/s10461014-0870-4

6. Departemen Kesehatan Republik Indonesia. 2007. Pedoman Nasional Penanggulangan Tuberkulosis. Edisi Kedua. Cetakan Pertama. Jakarta.

7. Gupta, Krishna Bihari. 2009. Journal Tuberculosis and Nutrition. 2009; Vol. 26

8. Intiyati. Ani, Abdul Mukhis, Yessy Dessy Arna, Siti Fatimah. 2012. Hubungan status gizi dengan kesembuhan penderita TB Paru di Poli Paru di RSD Sidoarjo. The Indonesian Journal of Health Science, Vol. 3, No. 1, Desember 2012

9. Kementerian Kesehatan Republik Indonesia. 2014. Pedoman Nasional Pengendalian Tuberkulosis. Jakarta.

10. Khairil umam, Yulia Ramdhani, Zulfikar. 2017. Efek Kadar Albumin Terhadap Perbaikan Klinis Pasien TB di Poli Instalasi Pelayanan Tuberkulosis Terpadu (PTT) RSUD dr. Zainoel Abidin Banda Aceh. Jurnal Ilmiah Mahasiswa Kedokteran Biomedis 2(4) : 8-14: November 2017.

11. Khariroh S. 2006. Faktor Resiko Gagal Konversi BTA Sputum Penderita TB Paru Setelah Program Pengobatan DOTS Fase Intensif di RSU Soetomo dan BP4 Karang Tembok Surabaya : Universitas Airlangga.

12. Kulsum. Iceu Dimas, Erlina Burhan, Rochismandoko. 2017. Faktor yang Mempengaruhi Konversi Sputum BTA Mikroskopik pada Pasien Tuberkulosis Paru Kasus Baru dengan Diabetes Mellitus. J Respir Indo Vol. 37 No. 2 April 2017.

13. Lassen, KO., Jens, O., Edvin, G., Filip, K., dan Merete, B. 2006. Nutritional Care of Medical in Patients: A Health Technology Assessment. Biomedical Central Journal. 1086: 6963-7.

14. Liu PT, Modlin RL. 2008. Human macrophage host defense against
Mycobacterium tuberculosis. Curr Opin Immunol. 8;20(4):371-6

15. Lönnroth K. 2011. Risk factors and social determinants of TB [online]. Available from:http://www.bc.lung.ca/association_a nd_services/documents/KnutUnionNART B riskfactorsanddeterminantsFeb2011.

16. Martina AD. 2012. Hubungan Usia, Jenis Kelamin dan Status Nutrisi Dengan Kejadian Anemia Pada Pasien Tuberkulosis. Universitas Diponegoro, Semarang.

17. Matos ED, Lemos ACM. Association between Serum Albumin Levels and inhospital Deaths due to Tuberculosis.2006;10(12):1360-6.

18. Memon AR, Naz R. Protein and Albumin Level in Pulmonary Tuberculosis. Sindh, Pakistan. New York Science Journal 2014;7(8)

19. Mercer, T., Craig, A. J., Kevin, E., Yarasheski., Nadine, S.,Wayne, W., C.Anna, E. 2007. Nutrient Ingestion, Protein Intake, and Sex, but Not Age, Affect the Albumin Synthesis Rate in Humans. American Society for Nutrition. 134:1734-40.

20. Prastowo. Agus, Wiryatun Lestariana, Siti Nurdjanah dan Retno Sutomo. 2016. Keefektifan Putih Telur Terhadap Peningkatan Albumin dan IL-6 Pada Pasien Tuberkulosis dengan Hipoalbumin. Jurnal Kesehatan, ISSN 1979-7621, Vol. 1, No. 1, Juni 2016: 1018

21. Pratomo I Putra, Burhan E, Tambunan V. 2012. Malnutrisi dan Tuberkulosis. J Indon Med Assoc. 2012 June; 62(6):231.

22. Puspita, Elsa. Erwin Christianto dan Indra Yovi. 2016. Gambaran Status Gizi Pada Pasien Tuberkulosis Paru (TB Paru) yang menjalani Rawat Jalan Di RSUD Arifin Achmad Pekanbaru. JOM FK Volume 3 No. 2 Oktober 2016

23. Simbolon. Harsa, Julia Lombo dan Maarthen Pongkar. 2016. Hubungan 
Indeks Massa Tubuh dengan Kadar Albumin Pada Pasien Tuberkulosis Paru. Jurnal e-Clinic Vol 4 No. 2 JuliDesember 2016.

24. Sridevi D, editor: Thomas M Wheeler. 2015. Albumin. Medscape emedicine.

25. Suliyanti. 2013. Gambaran status gizi dan tingkat konsumsi energi protein pada penderita tuberkulosis paru di Puskesmas Medan Johor. Fakultas Kesehatan Masyarakat Universitas Sumatera Utara. Medan.

26. Tabrani I. 2007. Konversi Sputum BTA Pada Fase Intensif TB Paru Kategori I Antara Konbinasi Dosis Tetap dan Obat Anti Tuberkulosis Generik di RSUP H. Adam Malik Medan. Tesis, Universitas Sumatera Utara.

27. Tama. Tika Dewi, Asri Adisasmita dan Erlina Burhan. 2016. Indeks Massa Tubuh dan Waktu Terjadinya Konversi Sputum pada Pasien TB Paru BTA Positif di RSU Persahabatan. Jurnal Epidermiologo Kesehatan Indonesia, Vol. 1 No. 1 November 2016.
28. Usman, Suwarno. 2008. Konversi BTA pada Pasien TB paru Kategori I dengan Berat Badan Rendah dibandingkan dengan Berat Badan Normal yang Mendapatkan Terapi Intensif. Tesis. Sekolah Pascasarjana Universitas Sumatera Utara.

29. Werdhani, Retno Asti. 2009. Patofisiologi, Diagnosis dan Klasifikasi Tuberkulosis. Departemen Ilmu Kedokteran Komunitas, Okupasi dan Keluarga. Fakultas Kedokteran Universitas Indonesia.

30. Wijaya, Geraldi Kusuma. 2015. Pengaruh Kapsul Ekstrak Ikan Gabus (Chana Striata) Terhadap Kadar Albumin Pada Pasien Tuberkulosis Paru Pengobatan Fase Intensif. Fakultas Kedokteran Universitas Jember.

31. Wokas, Jonathan, Wongkar dan Eko Surachmanto. 2015. Hubungan antara Status Gizi, Sputum BTA dengan Gambaran Rontgen Paru Pada pasien Tuberkulosis. Jurnal e-Clinic (eCl), Volume 3, Nomor 1, Januari-April 2015

32. World Health Organization. 2015. Tb situation and access to care. Global tuberculosis Report 